\title{
Fake news. A continuation or rejection of the traditional news paradigm?
}

Information journalism is based on several main assumptions: (1) the communicated items of news are true; (2) the classical model of a news story has an upside down pyramid structure, and its text answers the questions of: who, what, where, when, why, etc.; (3) the information must be reliable, precise, and credible. Those are the principles that have accompanied journalism for many years. However, that paradigm is now in danger. Truth is being replaced by posttruth, and stories news by fake news.

The creation of fake news is nothing new. Alexandra Kitty in her book Don't Believe It! How Lies Become News (2005) discusses many such cases. In 2002, Christopher Newton, an Associated Press reporter, quoted the statements of two criminologists regarding the extent of crime. One of them supposedly worked at Stanford University, the other was supposed to be an expert at the Institute for Crime and Punishment, a Chicago-based think tank. The story was reprinted by several American newspapers, i.a. The Washington Post. The deceit was only discovered by a New York Times reporter. It turned out that none of the quoted experts had ever existed. Neither had there ever been a think tank of that name'. In the San Jose Mercury News newspaper a student intern there quoted over thirty times sources with whom he had never spoken (1999)2. In 2003, there was the widely-discussed case of Jason Blair of The New York Times. Blair copied other people's news stories, included interviews with people he had never met, and wrote reports from places he had never visited. His plagiaristic journalism was condemned, and he was fired from the NYT together with his superiors: Howell

* PhD, e-mail: marekpalczewski@wp.pl; Chair of Journalism and Social Communication, Faculty of Humanities and Social Sciences, University of Social Sciences and Humanities in Warsaw.

${ }^{1}$ A. Kitty, "Don’t Believe It! How Lies Become News", The Disinformation Company Ltd., New York 2005, p. 225.

${ }^{2}$ Ibid., pp. 225-226. Eric R. Drudis, student at Northwestern University's Medill School of Journalism, fabricated, e.g. the story about a girl who beat up her boyfriend for not wanting to kiss her. 
Raines and Gerald Boyd ${ }^{3}$. A few years earlier, in 1996-1998, Stephen Glass of The New Republican wrote 27 articles partly or entirely made up (out of 41 he wrote in total); he mixed actual events with fabricated ones, and quoted people who had never existed ${ }^{4}$. In 1980, Janet Cooke of The Washington Post fabricated a report on an 8-year-old boy who had been injected with drugs by his step father ${ }^{5}$. Even if the first case could be classified as plagiarism news, the other two surely belonged to the so-called fake news referred to herein. Many such stories would not have occurred if the editorial boards had observed their obligation to verify facts closely, and if the above-mentioned journalists/fabricators of news stories had not enjoyed the excessive trust of their superiors.

The problem of fakes (fake news) is certainly part of a more general category of journalistic deception. Elliot and Culver defined it as "an act of communicating messages not only by lying but also by withholding information, as to lead someone to have a false belief" ". Concealment of information is one of the methods of manipulation. In this context, fake news may also be considered as a form of disinformation and manipulation. However, in this article, I will consider fake news mainly as a type of false information existing both in traditional media (press, radio, television), and electronic media (websites, e-newspapers, Twitter, Facebook). I shall discuss the historical examples of fake news, their essence, the ontological difference between a fake piece of news and a "real" piece of news, the types of fake news, their role in contemporary journalism and in the possible future, and their influence on the social and political reality.

\section{A news in journalistic codes of conduct}

TVP S.A.'s journalist code of conduct includes guidelines stating that information ought to be separated from commentary and opinions, and be balanced and precise; it should be based on reliable sources so that the viewers can differentiate facts from speculation and hearsay ${ }^{7}$. Similar entries are included in the Code of journalistic conduct of the Association of Polish Journalists ${ }^{8}$.

${ }^{3}$ A. Kitty, op. cit., pp. 237-240; R. Dickinson, "Making up the news: journalism, deviance and social control in news production", in: "The Routledge Companion to News and Journalism Studies", S. Allan (ed.), Routledge, London and New York 2012, p. 223.

${ }^{4}$ A. Kitty, op. cit., pp. 234-240.

${ }^{5}$ Ibid., pp. 232-233.

${ }^{6}$ D. Elliot, Ch. Culver, "Defining and analyzing journalistic deception", Journal of Mass Ethics 1992, Issue 7 (2), pp. 69-74.

${ }^{7}$ https://s.tvp.pl/repository/attachment/0/e/e/0eea386c0fa98ad0c49f73f1a9f7c8e7144534797 7947.pdf [accessed on: 30.03.2017].

${ }^{8} \mathrm{http://sdp.pl/s/kodeks-etyki-dziennikarskiej-sdp} \mathrm{[accessed} \mathrm{on:} \mathrm{30.03.2017].}$ 
In its very first sentence, the Journalistic Code of Conduct of the Association of Journalists of the Republic of Poland states that "The basic ethical responsibility of a journalist is to seek and publish the truth". It then goes on to state that "any manipulation of the facts is prohibited"9.

The entire journalistic community holds in high esteem the Ethical Media Charter (Karta Etyczna Mediów). Its first principle is the principle of truth which stipulates that "[...] the communicated information be in line with the truth and reliable, and to report facts without any distortions in their appropriate context, and if an incorrect piece of information was propagated, it should be corrected immediately"10.

The Declaration of the Principles on the Conduct of Journalists of the International Federation of Journalists states that "Respect for truth is the first obligation of a journalist"11. American codes of conduct state the need to "seek truth and report it" (Code of Ethics, Society of Professional Journalists) ${ }^{12}$, while the ASNE Statement of Principles in a section regarding Truth and Accuracy states: "Every effort must be made to assure that the news content is accurate, free from bias and in context, and that all sides are presented fairly"13.

That short review of codes clearly indicates that none of them permits any manipulation of the facts, and the assumption that a news story communicates truth or is an expression of a search for such, is the central notion around which the communication of information is organised.

\section{Fake news in the history of journalism}

The existence of false news which did not include descriptions of an actual state of reality has a very long history reaching as far back as antiquity. The Acta Diurna, a proto-newspaper of $47 \mathrm{AD}$ - a fact which was reported by Pliny the Elder - included information on the phoenix, a mythical bird which was supposedly displayed in Rome ${ }^{14}$. In 1747, Benjamin Franklin published in the London General Advertiser the statement of a young mother Polly Baker accused of extramarital sex. The speech was supposed to have made such an impression on the jury that they acquitted her of the charges. 30 years later Franklin admitted that he had invented

\footnotetext{
${ }^{9} \mathrm{http}: / /$ www.dziennikarzerp.pl/wp-content/uploads/2010/06/kodeks.pdf [accessed on 30.03.2017].

${ }^{10} \mathrm{http} / / / \mathrm{www} . d z i e n n i k a r z e r p . p l / w p-c o n t e n t / u p l o a d s / 2010 / 06 /$ karta_dziennikarzy.pdf [accessed on: 30.03.2017].

${ }^{11} \mathrm{http}$ ://www.ifj.org/about-ifj/ifj-code-of-principles/ [accessed on: 30.03.2017].

12 https://www.spj.org/pdf/spj-code-of-ethics.pdf [accessed on: 30.03.2017].

${ }^{13} \mathrm{http}: / /$ asne.org/content.asp?contentid=171 [accessed on: 30.03.2017].

${ }^{14}$ M. Stephens, "A History of news", New York, Oxford University Press 2007, p. 57.
} 
Polly Baker ${ }^{15}$. The $19^{\text {th }}$ and $20^{\text {th }}$ centuries offered many news stories which resulted in wars (not always directly but through manipulated influence), e.g. the Spanish-American War of 1898, a news story on the Gulf of Tonkin incident which started the war in Vietnam, and the story on weapons of mass destruction which were supposedly held by Saddam Hussein. The existence of WMD was used as a pretext to start the Second Iraqi War. These latter could be referred to as propaganda news considering the goal for which they were fabricated.

One of the biggest scandals was the fabrication of a media fact by the CNN journalist Peter Arnett, who accused the USA of using the prohibited sarin gas against the civilian population during a covert operation in Laos. It later turned out that what was actually used was not sarin but tear gas, and not against the civilian population but armed Vietnamese. In TVP, the Polish public television, the host of an opinion show released a fabricated news story that one of the leaders of the opposition had been arrested. It was supposed to serve as an illustration to a discussion on post-truth, yet it had become an example of fake news.

There have been "news" stories published via Twitter or Facebook regarding the death of the singer Gotie, an assassination on Barack Obama, stories on the stealing of furniture from the White House by Hilary Clinton and her collaboration with terrorists, and many other which constituted examples of the so-called posttruth. In her book, Kitty provided examples of dozens if not hundreds of fake news items. They included some amusing stories. In 1917, a New York Evening Mail journalist Henry Louis Mencken wrote an article about the history of the bathtub recalling the reasons and events which led to the installation of the first bathtub in the White House by president Millard Filmore (held office in 1850-1853). It turned out that Mencken had fabricated his story. Other newspapers repeated it indiscriminately with The Washington Times quoting Mencken's report 75 years after it had originally been published.

In the Polish media market, there have also appeared instances of fake news. Some of the more widely known included the alleged death of actor Andrzej Grabowski ${ }^{16}$, the false news on the early death of Gen. Wojciech Jaruzelski, and the manipulations associated with the statements made by the French presidential candidate Marine Le Pen, who, during a meeting with journalists, was supposed to have said that she would dismantle the EU in cooperation with Jarosław Kaczyński, the leader of the Polish party Law and Justice (PiS) ${ }^{17}$. Tabloids

\footnotetext{
${ }^{15}$ A. Kitty, op. cit., p. 227.

${ }^{16} \mathrm{http} / / /$ www.se.pl/rozrywka/gwiazdy/ferdynand-kiepski-nie-zyje-andrzej-grabowski-na-facebooku-uwaga_486125.html [accessed on: 30.03.2017].

$17 \mathrm{http}: / /$ wiadomosci.gazeta.pl/wiadomosci/7,114881,21489598, marine-le-pen-chce-sojuszu-zjaroslawem-kaczynskim-zloze-mu.html [accessed on 30.03.2017]. The title of the original article which had been published on Rzeczpospolita's website was changed by the editorial board when it turn out that it included a fabricated quotation from Marine Le Pen from her meeting with journalists.
} 
have long specialised in fake news, however, the news stories about a whale swimming up the Vistula towards Warsaw, extraterrestrials, and flying hamsters were entertainment-focussed and were rarely considered as serious or real ${ }^{18}$. Today, much fake news is created in posts underneath e-newspaper articles and in information sections of websites. They may refer, for instance, to fabricated cases of aggression of refugees/immigrants from Arabic countries against the indigenous inhabitants of Europe. It is difficult to combat such news stories as there are no tools for verifying them, though some European states (e.g. Norway, Germany, France, and Sweden) are introducing complex procedures for verifying their reliability which will enable them to exclude fake ones from circulation ${ }^{19}$.

Twitter is particularly sensitive to people publishing fake news as it is considered by various media outlets and journalists as a reliable source of information, which it obviously is not ${ }^{20}$. On 11 November 2013, there appeared on Twitter posts by one of the leaders of Ruch Narodowy (National Movement) Artur Zawisza, who supposedly complimented the actions of rioters who tried to set fire to the fence of the Russian embassy. He allegedly posted on his profile: "God, honour, fatherland! The Marshal would have been proud", to add a day later: "The time of true patriots will come one day" 21 . It turned out that Zawisza had a different account, and the quoted @ZrturZawiszal was a fake one. Fake news was also posted on the profiles of the former president of Poland Bronisław Komorowski, and the alleged accounts of PiS politicians: Jarosław Kaczyński and Antoni Macierewicz. The best known and resounding slip up was made by Tomasz Lis, a journalist, in a talk show he hosted when he assigned to Kinga Duda, daughter of Andrzej Duda, a candidate in the Polish presidential election, a statement published on her fake Twitter account. She was supposed to have posted that when her father becomes president, he would return the Oscar for the film "Ida" 22 . The account was fake, and the journalist had to apologise for his mistake.

\footnotetext{
${ }^{18}$ M. Palczewski, "Kilka uwag o tabloidyzacji newsa", in: "News i dziennikarstwo śledcze wobec wyzwań XXI wieku”, M. Palczewski, M. Worsowicz (eds.), Wydawnictwo Wyższej Szkoły Humanistyczno-Ekonomicznej, Lodz 2010, p. 82.

19 https://www.theguardian.com/technology/2016/dec/16/facebook-fake-news-system-problems-fact-checking [accessed on: 30.03.2017]; https:/www.bloomberg.com/news/articles/2017-01-11/ facebook-s-journalism-project-pledges-stronger-media-ties [accessed on: 30.03.2017]; https://www. document.no/2017/03/22/fake-news-faktisk/ [accessed on: 30.03.2017]; http:/www.stopfake.org/ en/tag/sweden/ [accessed on: 30.03.2017].

${ }^{20}$ M. Palczewski, “Twitter jako ponowoczesne źródło informacji”, Dziennikarstwo i Media 2014, Issue 4, pp. 175-196.

${ }^{21} \mathrm{https}$ ://twitter.com/ArturZawisza1 [accessed on: 04.12.2013].

$22 \mathrm{http}$ //wiadomosci.wp.pl/wpadka-w-programie-tomasz-lis-na-zywo-cytowali-wpis-z-falszywego-konta-kingi-dudy-6025251166573185a [accessed on: 30.03.2017].
} 


\section{The essence of fake news}

Let us examine one instance of fake news which was posted by hackers to the Twitter account of the American television station Fox News ${ }^{23}$ :

Fake news

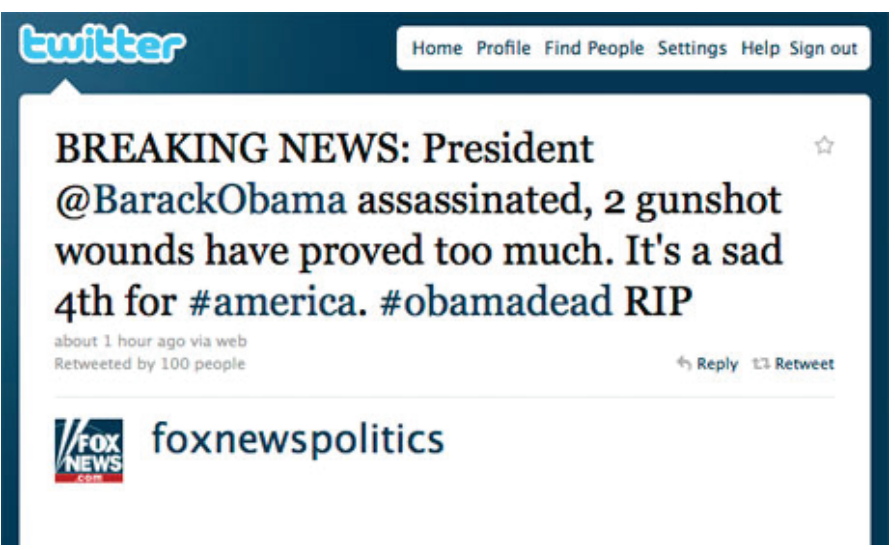

Sourse: own screenshot.

The murder was supposed to have taken place at 2 a.m. in a restaurant in Iowa. Consecutive stories described the place where the president was shot. The structure of a fake news is similar to that of a real news story. It answers the basic questions of who, what, where, and when. In this case, what was missing were specific details on who reported the event (the question of the source), who witnessed it, and the exact information on the place and a detailed description of who accompanied the president, why he was in that exact location, etc. Then again, it is commonly accepted that tweets are laconic (due to the fact that they can only include up to 140 characters), and only later are they expanded upon by traditional media.

Fake news can offer a detailed description of an event, including quotes, references to event participants and witnesses, and it can offer a closer and more extensive historical context. It can be entirely based on untrue fabricated "facts" (Stephen Glass's "news") or only partly rearrange and reformulate actual events. In that sense, fake news is manipulated news subjected to special processing. Real facts are supplemented with fabricated fragments, quotes of false witnesses, false background is added, and false locations, dates and times

${ }^{23} \mathrm{https} / /$ www.theguardian.com/news/blog/2011/jul/04/fox-news-hacked-twitter-obama-dead [accessed on: 30.03.2017]. 
can also be indicated. However, in terms of the structure of a piece of fake news, it is identical to the structure of a genuine piece of news. It can include the same elements, it can consist of sentences identical in terms of their grammatical form.

One definition of a piece of fake news states that it is a message communicated from the source by a journalist to the public, and subjected to processing by a media organisation; a message the main function of which is notification ${ }^{24}$. These features could refer to both genuine and false pieces of information. A news story is also, or maybe mainly, defined by assigning it the function of notification. Fake news also possesses that feature until one identifies the ontological difference which makes the reference of fake news to extra-news reality irrelevant. Thus its nature consists in the function of non-notification or an intentional misleading. Examples of fake news created by well-known and respected media organisations or relayed by them to receivers from other sources indicate that regardless of maintaining the complex process of developing news specific for the media, it is still possible to make the mistake of relaying false pieces of information. For example, the process of verification of articles at The New Republican, where Stephen Glass worked, was very meticulous, and yet 27 out of his 41 articles included fake news. Janet Cooke worked at The Washington Post on her report, which later proved to be fabricated, under the supervision of an expert investigative journalist Bob Woodward, and yet no one questioned its authenticity prior to its publication. The examples of news stories from Rzeczpospolita, CNN, and The Washington Post only confirm the assumption that in many cases the receivers are not able to verify a piece of information, especially when journalistic reports and descriptions are based solely on reporter notes, or when their only source is an anonymous informer, whose identity is known only to the journalist and it cannot be revealed due to the right to remain secret held by the source. In such a situation, the one thing a person can do is trust the journalist that she/he says/writes the truth, which, as the examples discussed above showed, is not alwaysan effective method of verifying the authenticity of information.

${ }^{24}$ Cf. the definition in: H. Gans, "Deciding What's News: A study of CBS evening news, NBC nightly news, Newsweek and Time”, Northwestern University Press, Evanston, Illinois 2004 (1st edition: New York: Pantheon 1979), p. 80: "I view news as information which is transmitted from sources to audiences, with journalists - who are both employees bureaucratic commercial organizations and members of a profession - summarizing, refining, and altering what becomes available to them from sources in order to make the information suitable for their audiences". 


\section{Differences between fake news and news}

The ontological difference is of first importance, as all others result from it. Its essence is that fake news has no reference, i.e. does not refer to any "extranews" reality. Even if one takes the constructivist view that a news story is a construct of reality, then fake news items are constructs devoid of that reality. A real news story - considered as such by journalists - possesses, i.a. qualities of genuineness, objectivity, materiality, authenticity, reliability, precision, credibility, and verifiability. That is why fake news is usually difficult to verify as it does not include as its reference any objective reality understood, e.g. within the categories of inter-subjectivity. Fake news is subjectively hollow, its objective marker is nonexistent, and therefore (usually) cannot be verified. Its ontology remain fictional, while its epistemology is the inability to recognise this and reach the truth due to the subjective solipsism of the recognising subject. Putting matters simply: a fabricated news story "sits" inside the head of its creator. Creators of fake news do not care for the truth; they are only focussed on achieving favourable results through communicating untrue pieces of information ${ }^{25}$.

Another difference is of an ethical character. A news story which is a real piece of information should be objective, carefully selected, precisely studied with care for maintaining the relationship between the piece of information and the described reality, diligently communicated, and based on the honest attitude of a journalist who is clearly not trying to fabricate reality, but to seek the truth, while fake news does not include any of those features. It is intentionally fraudulent, its goal is to deceive the receiver, often with an underlying aim of achieving a material, political, personal, or group gain. The goal of fake news can also be to entertain or excite (such a function was fulfilled by the stories about the whale in the Vistula, the Loch Ness monster, the extraterrestrials in Emilcin, etc.), but even in that case it would be difficult not to notice their commercial aspect.

However, one should differentiate fake news from journalistic provocation, which is also sometimes based on deceit, intentionally misleading the interlocutor, or creating a false situation through which the investigative journalist can achieve her/his intended goal which could not be achieved otherwise (e.g. the provocation of The Chicago Sun-Times journalists who opened the Mirage bar to catch corrupt officials red-handed) ${ }^{26}$. In the latter case, the fabrication is, however, only a method leading to a goal impossible to be achieved through traditional

\footnotetext{
${ }^{25}$ Cf. P. Levinson, "Fake News in Real Context", Connected Editions Inc., New York City 2016-2017.

${ }^{26}$ Z.N. Smith, P. Zekman, “The Mirage”, Random House, New York 1979.
} 
means, and the fabrication is revealed to the receivers in the journalistic material and described as a part of the journalistic investigation. It is to the contrary with fake news items, the "real" essence of which remains hidden from the reader, and they do not serve "the truth" as they are lies, fabrications, serving political, entertainment, or commercial ends.

\section{Types of fake news}

Based on the above-mentioned examples, one can develop a general classification of fake news items, which differ mainly in terms of their intentionality, and precision of description. The topic is not important, just like in the case of a real news story, as it does not determine the genre features of a text.

Therefore, fake news can be divided into:

1) Intentionally untrue fake news, satirical, "with a pinch of salt" (satire news, etc.), sometimes referred to as truthiness ${ }^{27}$;

2) Fake news which imitates real news, but is completely fabricated;

3) Fake news created on the basis of real news, subjected to manipulation;

4) Real news referred to as fake only because someone did not like it ${ }^{28}$.

One should not consider as fake news those pieces of information which were reported "in good faith", corrected pieces of news, accidentally incorrect or unverified, which were later shown to be false. In the case of news stories in 1 and 2, those are news stories which were completely made up (2) or which in a satirical way commented on actual events (1), thus shifting the emphasis of official interpretations towards the satirical interpretation. The third type applies to news stories which were created by adding a fabricated "fact" (or "facts") either to stories already present in the public sphere, or to just created stories which mainly include real information, but the additional component turns them into fake news. Fake news of the third type is particularly dangerous as it is difficult to question its authenticity, and it is basically only possible upon multi-faceted comparative studies of the event itself using proper observation and seeking its sources, or through juxtaposing (triangulating) all available descriptions of a given event published by the media, with particular consideration of those media which are considered trustworthy.

${ }^{27}$ On truthiness vide: "The Changing faces of Journalism. Tabloidization, Technology and Truthiness", B. Zelizer (ed.), Routledge, London and New York 2009.

28 The last type of fake news was indicated by Paul Levinson in the quoted essay "Fake News in Real Context". 


\section{The role of fake news and its influence on public opinion}

The influence of fake news on public opinion may be the same or even bigger than that of real news stories. A piece of fake news on the attack on a Gliwice radio station carried out by Poles was used by Germans as a pretext to start WWII; the Tonkin incident (provoked by Americans) started the Vietnam War; and the (false) information on weapons of mass destruction (WMD) held by Saddam Hussein enabled the Americans to acquire public support for the attack on Iraq. However, a media user usually does not have the opportunity to verify that type of information. Just as she/ he does not possess the tools to verify data or descriptions of events published on Facebook, Twitter, or in the form of posts under e-newspaper articles or websites. Fake news is repeated, processed, tweeted, propagated through various online channels and thus acquires the markers of "authenticity", in line with Goebbels's propaganda principle that a lie repeated a thousand times become the truth. The lies propagated on the web by Donald Trump's supporters against Hillary Clinton largely led to shattering her chances of winning the presidential election in the United States. There are numerous examples of the influence of lies exceeding that of the truth, e.g. the previously mentioned incidents which were used as pretexts for starting armed operations. Additionally, fake news possesses the advantage that it draws people's attention through its attractiveness, it exerts an emotional influence on the receivers, and satisfy their needs by matching their views and attitudes.

\section{Conclusions}

Fake news has become an almost indispensable element of the media-created landscape. The conducted analysis indicated that it are not a continuation of the existing paradigm of a news story even though it possesses properties which conceal its essence and mislead the receivers. It is very difficult to protect oneself against fake news due to the above-discussed factors. The attempts made in some countries consisting of creating platforms which verify the authenticity of news are important, yet they will not eliminate the problem. For that, it is necessary to implement a long-term educational policy indicating media manipulation, and which will develop people's skills for finding reliable sources, the trustworthiness of which is ensured by verified, honest and professional journalism. However, one must be aware of the fact that fake news might, as Paul Levinson noted, be a part of our reality, with which we will have to learn to live ${ }^{29}$.

${ }^{29}$ P. Levinson, op. cit.: "But just as we can never eradicate all disease-causing viruses and bacteria we can expect to be in a never - ending battle with fake news. Like illness, fake news is a part of life". 


\section{Bibliography}

Dickinson R., "Making up the news: journalism, deviance and social control in news production", in: "The Routledge Companion to News and Journalism Studies", S. Allan (ed.), Routledge, London and New York 2012, p. 223-233.

Elliot D., Culver Ch., "Defining and analyzing journalistic deception", Journal of Mass Ethics 1992, Issue 7 (2), pp. 69-74.

Gans H., "Deciding What's News: A study of CBS evening news, NBC nightly news, Newsweek and Time", Northwestern University Press, Evanston, Illinois 2004 (1st edition: New York: Pantheon 1979).

Kitty A., “Don’t Believe It! How Lies Become News”, The Disinformation Company Ltd., New York 2005.

Levinson P., "Fake News in Real Context”, Connected Editions Inc., New York City 2016-2017.

Palczewski M., "Kilka uwag o tabloidyzacji newsa", in: "News i dziennikarstwo śledcze wobec wyzwań XXI wieku”, M. Palczewski, M. Worsowicz (eds.), Wydawnictwo Wyższej Szkoły Humanistyczno-Ekonomicznej, Lodz 2010, p. 73-84.

Palczewski M., “Twitter jako ponowoczesne źródło informacji”, Dziennikarstwo i Media 2014, Issue 4, pp. 175-196.

Smith Z.N., Zekman P., “The Mirage”, Random House, New York-Toronto 1979.

Stephens M., "A History of news", New York, Oxford University Press 2007.

"The Changing faces of Journalism. Tabloidization, Technology and Truthiness", B. Zelizer (ed.), Routledge, London and New York 2009.

\section{Internet sources}

http://asne.org/content.asp?contentid=171 [accessed on: 30.03.2017].

http://sdp.pl/s/kodeks-etyki-dziennikarskiej-sdp [accessed on: 30.03.2017].

http://wiadomosci.gazeta.pl/wiadomosci/7,114881,21489598, marine-le-pen-chce-sojuszu-z-

-jaroslawem-kaczynskim-zloze-mu.html [accessed on: 30.03.2017].

http://wiadomosci.wp.pl/wpadka-w-programie-tomasz-lis-na-zywo-cytowali-wpis-z-falszywego-konta-kingi-dudy-6025251166573185a [accessed on: 30.03.2017].

http://www.dziennikarzerp.pl/wp-content/uploads/2010/06/karta_dziennikarzy.pdf [accessed on: 30.03.2017].

http://www.dziennikarzerp.pl/wp-content/uploads/2010/06/kodeks.pdf [accessed on: 30.03.2017]. http://www.ifj.org/about-ifj/ifj-code-of-principles/ [accessed on: 30.03.2017].

http://www.se.pl/rozrywka/gwiazdy/ferdynand-kiepski-nie-zyje-andrzej-grabowski-na-faceboo-

ku-uwaga_486125.html [accessed on: 30.03.2017].

http://www.stopfake.org/en/tag/sweden/ [accessed on: 30.03.2017].

https://s.tvp.pl/repository/attachment/0/e/e/0eea386c0fa98ad0c49f73f1a9f7c8e71445347977947.

pdf [accessed on: 30.03.2017].

https://twitter.com/ArturZawisza1 [accessed on: 04.12.2013].

https://www.bloomberg.com/news/articles/2017-01-11/facebook-s-journalism-project-pledges-

-stronger-media-ties [accessed on: 30.03.2017].

https://www.document.no/2017/03/22/fake-news-faktisk/ [accessed on: 30.03.2017].

https://www.spj.org/pdf/spj-code-of-ethics.pdf [accessed on: 30.03.2017]. 
https://www.theguardian.com/news/blog/2011/jul/04/fox-news-hacked-twitter-obama-dead [accessed on: 30.03.2017].

https://www.theguardian.com/technology/2016/dec/16/facebook-fake-news-system-problems-fact-checking [accessed on: 30.03.2017].

Marek Palczewski

Fake news. A continuation or rejection of the traditional news paradigm?

(Summary)

In the article, I analysed the problem of fake news in the context of the traditional paradigm of a news story. The traditional paradigm posits that, most of all, a piece of information is true. However in contemporary media, there exist pieces of information which are fabricated and untrue. It is not a new phenomenon, yet it has intensified in recent years. News stories are fabricated for entertainment, political, or commercial purposes. They are carriers of propaganda and profit. The essence of fake news is the intentional misleading of the receiver for achieving the above gains. It is difficult to verify their veracity, and identify fake news items due to their similarity to real pieces of news. That is why they are becoming a part of the media landscape in which we will probably have to exist.

Keywords: fake news, news paradigm, authenticity, media. 